\title{
Insulin and Growth Hormone Responses to Glucose Loading in Treated Acromegalics* **
}

\author{
H.K. Åkerblom***, P.R. NEmman, J.W. Meakin, J.M. Martin and W.J.K. Stmpson
}

The Research Institute, The Hospital for Sick Children, Toronto and The Princess Margaret Hospital, Toronto

Received: August 6, 1968

Summary. The insulin and growth hormone responses to oral glucose load $(100 \mathrm{~g})$ in 23 acromegalic patients, previously treated by external irradiation, are described. Based on current clinical findings, sixteen acromegalics were considered "inactive" and seven patients "active". Two of the latter were treated diabetics. Thirteen healthy, non-obese subjects formed the control group. Five "inactive" acromegalics had blood glucose values exceeding the upper limits of normal after the glucose load. Both the "inactive" and "active" acromegalics had hyperinsulinemia in the fasting state and after glucose load. The observation of an exaggerated serum insulin response to glucose load in clinically "inactive" acromegalics suggested that chronically elevated levels of circulating growth hormone may have led to permanent changes in the responsiveness of the pancreatic islets to glucose stimulation. The mean fasting value of serum growth hormone was about the same in the controls and the "inactive" acromegalics; the latter did not show suppression in serum growth hormone levels after glucose load.

Taux d'insuline et d'hormone de croissance à la suite d'une charge en glucose chez des acromégaliques déjà traités

Résumé. Le taux d'insuline et d'hormone de croissance à la suite d'une charge en glucose $(100 \mathrm{~g})$ par voie orale fut mesuré chez 23 acromégaliques qui avaient été traités par radiothérapie. Seize de ces patients étaient considérés cliniquement en phase «inactive» et les sept autres en phase kactiven. Deux de ces derniers étaient diabétiques et sous traitement. Treize sujets normaux, non obèses, formaient le groupe témoin. Cinq acromégaliques en phase (inactive» ont présenté à la suite d'une charge en glucose des valeurs de la glycémie dépassant les limites supérieures de la normale. Tous les acromégaliques en phase tactive" et "inactive" présentaient une hyperinsulinémie à l'état de jeûne et à la suite d'une charge en glucose. Cette observation d'une montée exagérée de l'insulinémie à la suite d'une charge en glucose chez des acromégaliques cliniquement «inactifs» suggère qu'un taux sérique d'hormone de croissance continuellement élevé peut avoir amené des changements permanents de la réponse des îlots du pancréas à la suite d'une stimulation venant du glucose. Les valours moyennes du taux sérique de l'hormone de croissance étaient semblables à l'état de jeûne chez le groupe des témoins et chez les acromégaliques en phase uinactive». Ces derniers n'ont pas présenté une baisse du taux sérique d'hormone de croissance à la suite d'une charge en glucose.

Der Verlauf der Seruminsulin- und Wachstumshormonwerte nach Glucosebelastung bei behandelien Akromegaten

Zusammenfassung. Die vorliegende Arbeit beschreibt den Verlauf der Seruminsulin- und Wachstumshormonwerte nach oraler Verabreichung von $100 \mathrm{~g}$ Glucose bei 23 Patienten mit Akromegalie, die früher mit Bestrahlung behandelt worden waren. Auf Grund der klinischen Befunde zum Zeitpunkt der Untersuchungen wurden sechzehn Patienten als "inalitive" und sieben Fälle als ,"aktive $^{65}$ Akromegale eingestuft. Zwei von den ,aktiven" Akromegalen waren behandelte Diabetiker. Dreizehn gesunde, nicht fettsüchtige Personen bildeten die Kontrollgruppe. Fünf ,inaktive" Akromegale hatten nach der Glucosebelastung Blutglucosewerte über dem Normbereich. Sowohl die ,inaktiven" als auch die ,aktiven" Akromegalen zeigten Hyperinsulinämie nüchtern und nach Glucosezufuhr. Die gesteigerte Insulinsekretion der klinisch ,inaktiven" Akromegalen nach Glucosebelastung kann bedeuten, daß chronisch erhöhte Spiegel des zirkulierenden Wachstumshormons möglicherweise zu stän. digen Veränderungen in der Reaktion der LANGERHANS'scHEN Inseln gegenüber Glucosestimulation geführt haben. Der durchschnittliche Serumwachstumshormonwert im Nüchternzustand war ungefähr der gleiche bei der Kontrollgruppe und bei ,inaktiven" Akromegalen; die letzteren wiesen keine Verminderung der Serumwachstumshormonwerte nach Glucoseverabreichung auf.

Key-words. Glucose load, insulin, growth hormone, acromegaly, pituitary irradiation, hyperinsulinism.
Flevated levels of circulating insulin in acromegalics in the fasting state [7] and after glucose loading [16, $20,1]$ are well documented. However, few reports are available on the effect of radiation treatment on the metabolic derangements found in acromegaly.

The usual assessment of activity or inactivity depends mainly on clinical and radiological findings. We have attempted to determine the value of insulin

* Presented in part at the meeting of the Canadian Society for Clinical Investigation, Toronto, January $17 \mathrm{th}, 1968$.

** Supported in part by Medical Research Council, Canada, and The Ontario Cancer Treatment and Research Foundation

*** Research Fellow, Medical Research Council of Canada, and growth hormone response to glucose loading as a further index of activity. For this purpose, we studied 23 patients treated for acromegaly by external irradiation.

\section{Patients and Methods}

Twenty-three acromegalic patients were subjected to a clinical and biochemical assessment as outpatients. They had been treated by external ixradiation $\left({ }^{60} \mathrm{Co}\right.$ in 22 and $X$-ray in 1 patient) with a mean dose of 3860 rads (range $3490-5600$ rads) to the pituitary area from one and a half to 21 years earlier, One patient had also had a partial hypophysectomy. For the study, the acromegalies were separated into two groups. One group consisted of 16 patients, who had shown some 
improvement of their acromegaly after treatment. They are referred to as "inactive". The remaining seven had had little or no improvement after treatment, and are referred to as "active". The classification was based on current clinical findings; which included overall assessment of headache, acral enlargement, visual fields, heel pad and skin thickness, size and shape of the sella turcica; and on a comparison between earlier and present blood glucose values in glucose tolerance tests, and between earlier and present values of serum inorganic phosphorus. The clinical aspects of the study will be reported separately.

Some clinical data, necessary as a background for our studies, are summarized in Table 1. The mean weight of the "inactive" acromegalics was $104.2 \pm$ $3.9 \%$ and that of the "active" acromegalics $118.8 \pm$ $4.1 \%$ of the average weights for men and women, according to Metropolitan Life Insurance Company table (1960). All patients were euthyroid.

Thirteen young and middle-aged, healthy, nonobese subjects (four females, nine males) were studied as a control group. The acromegalic subjects had taken
180 min after glucose administration. Sampling at 180 min was omitted in the controls.

Blood glucose was determined by the method of HOFFMAN [9] as adapted for autoanalyzer. The remain. ing blood, allowed to stand at room temperature until clot retraction, was centrifuged; the serum was frozen until the radioimmunoassays of serum insulin and growth hormone could be made. We measured serum insulin by the immunoassay method of HrRBIRT [8], using coated charcoal-dextran. Human insulin standards were used and the results are expressed in $\mu \mathrm{U} / \mathrm{ml}$. Growth hormone was determined by the MoRGAN technique [14] of double-antibody immunoassay and the results are given as $\mathrm{m} \mu \mathrm{g} / \mathrm{ml}(\mathrm{ng} / \mathrm{ml})$.

Student's $t$-test was applied to the differences. They were considered significant at the 5 per cent level.

\section{Results}

Blood glucose ( $B G$ ). The "active" acromegalics had significantly higher $B G$ values at 60 and 90 min after loading compared with the controls $(P<0.02$ in both

Table 1. Clinical Data on Acromegatic Patients

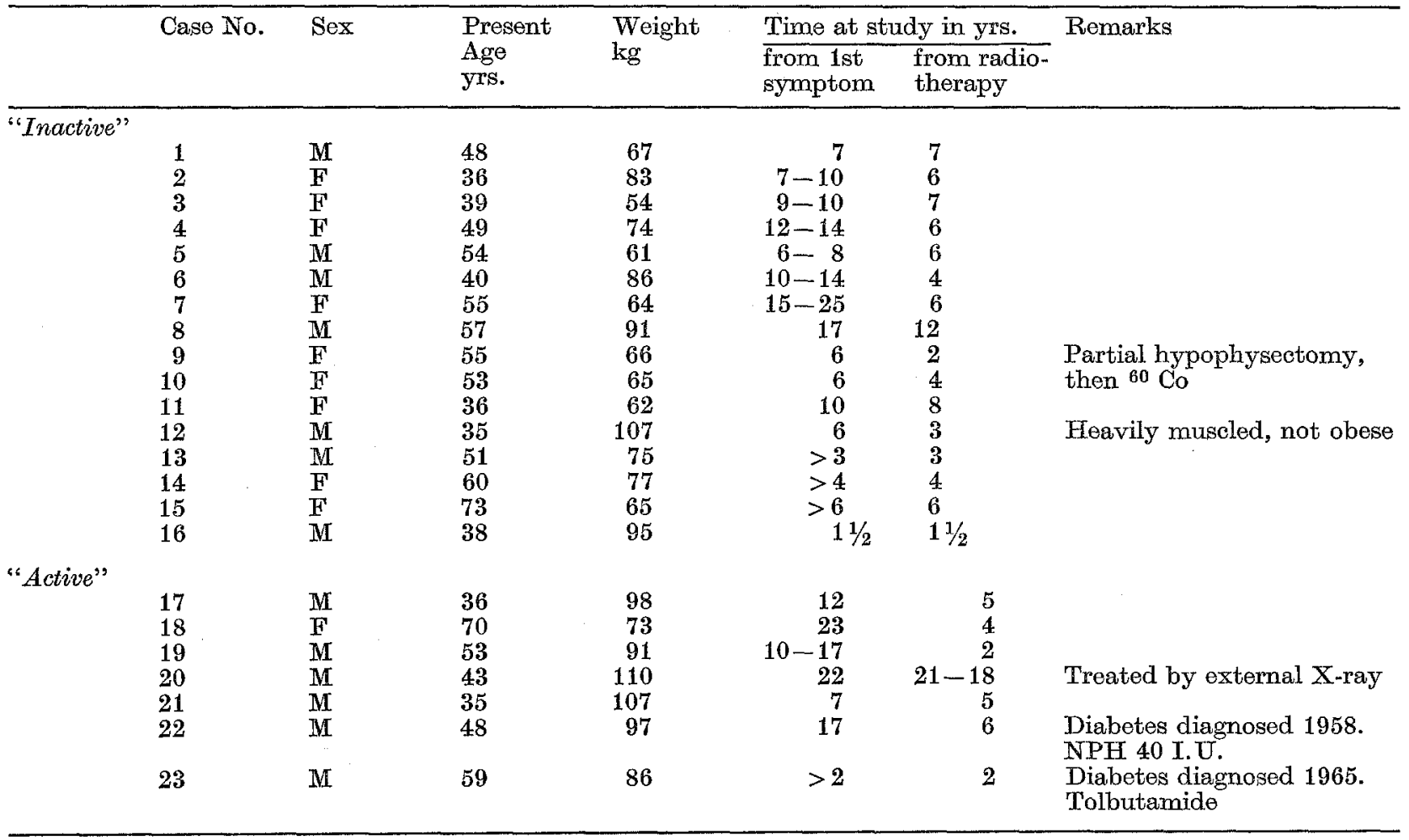

at least $300 \mathrm{~g}$ carbohydrate/day for three days before the test and the controls had taken adequate carbohydrates for a corresponding time. After an overnight fasting period and a one hour rest in the sitting position the subjects were given $100 \mathrm{~g}$ of glucose orally. Venous blood was drawn fasting and at $30,60,90,120$ and instances), and also at 90 min compared with the "inactive" acromegalics $(P<0.05)$ (Fig. 1).

The fasting BG was $112 \mathrm{mg} / 100 \mathrm{ml}$ in one "inactive" and in one "active" acromegalic patient. In addition, five other "inactive" patients and four "active" acromegalics had one or two BG values ex- 
ceeding the upper limits of normal for venous blood: $170 \mathrm{mg} / 100 \mathrm{ml}$ at 60 minutes, $120 \mathrm{mg} / 100 \mathrm{ml}$ at $120 \mathrm{~min}$, and/or $110 \mathrm{mg} / 100 \mathrm{ml}$ at $180 \mathrm{~min}$ [12].

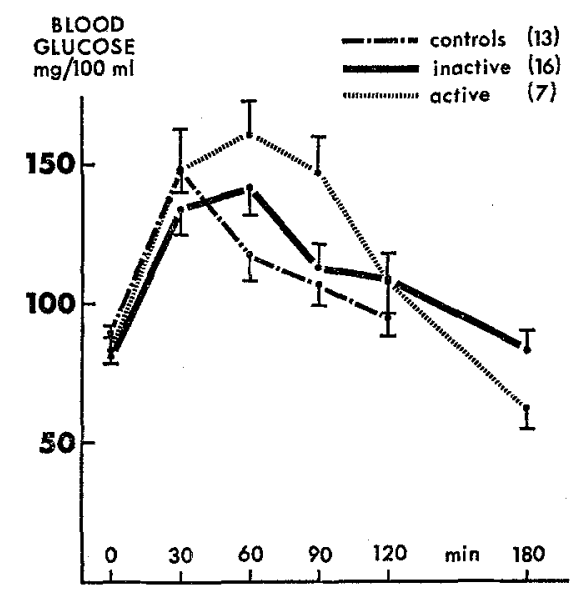

Fig. 1. Blood glucose response to $100 \mathrm{~g}$ glucose given orally, mean $\pm \mathrm{SE}$, in controls and "inactive" and "active" acromegalics

Serum insulin (IRI). The fasting level of serum IRI and the response of serum IRI to oral glucose load are shown in Fig. 2. The data on the two diabetics (cases \# 22 and \# 23) with active acromegaly, who received treatment for their diabetes, are not included. The fasting level of serum IRI in the "inactive" acromegalics was significantly higher than in the controls $(P<0.05)$. The hyperresponsiveness of serum IRI to glucose load in the "inactive" acromegalics was most pronounced at $90 \mathrm{~min}$, the mean value of IRI being significantly higher than in the controls $(P<0.05)$. The six "inactive" acromegalics with impaired glucose tolerance had hyperinsulinism both fasting and after glucose load, and their mean serum IRI values fasting
The ratio of serum $I R I$ to $B G$. The ratio of serum IRI to $\mathrm{BG}\left(\frac{\mu \mathrm{U} / \mathrm{ml}}{\mathrm{mg} / 100 \mathrm{ml}}\right)$, indicating the responsiveness

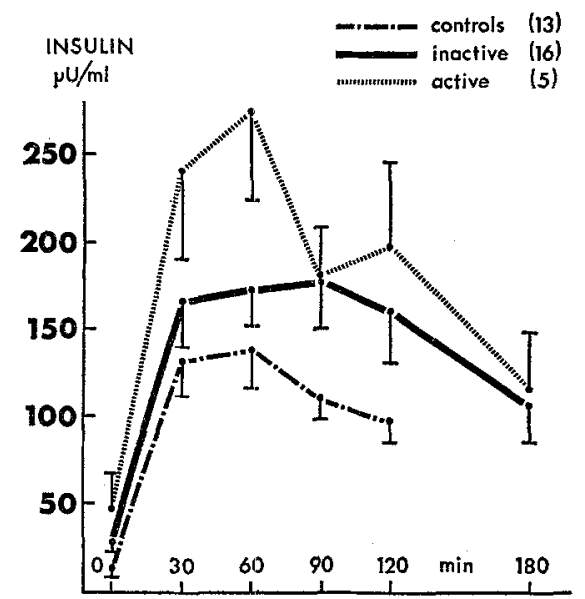

Fig. 2. Serum insulin $(\mu \mathrm{U} / \mathrm{ml})$, mean $\pm \mathrm{SE}$, before and after administration of $100 \mathrm{~g}$ glucose orally in controls and "inactive" and "active" acromegalics. Two "active" acromegalics who received treatment for their diabetes are not included

of the islets to stimulation by glucose, is presented in Table 2. The IRI/BG ratio was higher in the fasting state in the "inactive" acromegalics than in the controls $(P<0.05)$, although BG was higher in the latter. Comparison between the ratio of "inactive" acromegalics and controls after glucose administration and at times when the BG was about the same in both groups, did not show significant differences. However, the ratio tended to be higher in the "inactive" acromegalics. The six "inactive" acromegalics with impaired glucose tolerance had a higher mean fasting IRI/BG ratio than the controls $(P<0.05)$, the $\mathrm{BG}$ values being in both groups about equal.

Table 2. The ratio of serum insulin, $\mu U / \mathrm{ml}$, to blood glucose, $\mathrm{mg} / 100 \mathrm{ml}$, in oral glucose tolerance test in control and acromegalic subjects, mean $\pm S E$

\begin{tabular}{|c|c|c|c|c|c|c|}
\hline & 0 & $\begin{array}{l}30 \\
\min .\end{array}$ & $\begin{array}{l}60 \\
\min .\end{array}$ & $\begin{array}{l}90 \\
\text { min. }\end{array}$ & $\begin{array}{l}120 \\
\min .\end{array}$ & $\begin{array}{l}180 \\
\text { min. }\end{array}$ \\
\hline $\begin{array}{l}\text { Controls } \\
\text { (13) } \\
\text { "Inactive" }\end{array}$ & $\begin{array}{r}0.16 \\
\pm 0.05\end{array}$ & $\begin{array}{r}0.89 \\
\pm 0.13\end{array}$ & $\begin{array}{r}1.24 \\
\pm 0.18\end{array}$ & $\begin{array}{r}1.03 \\
\pm 0.12\end{array}$ & $\begin{array}{r}1.06 \\
\pm 0.15\end{array}$ & \\
\hline $\begin{array}{l}\text { acromegalics } \\
\text { (16) } \\
\text { "Active" }\end{array}$ & $\begin{array}{r}0.34 \\
\pm 0.06\end{array}$ & $\begin{array}{r}1.23 \\
\pm 0.20\end{array}$ & $\begin{array}{r}1.27 \\
\pm 0.17\end{array}$ & $\begin{array}{r}1.49 \\
\pm 0.26\end{array}$ & $\begin{array}{r}1.37 \\
\pm \quad 0.26\end{array}$ & $\begin{array}{r}1.26 \\
\pm 0.23\end{array}$ \\
\hline $\begin{array}{l}\text { acromegalics } \\
(5)^{\mathrm{a}}\end{array}$ & $\begin{array}{r}0.53 \\
\pm 0.18\end{array}$ & $\begin{array}{r}1.67 \\
\pm 0.42\end{array}$ & $\begin{array}{r}1.78 \\
\pm 0.38\end{array}$ & $\begin{array}{r}1.35 \\
\pm 0.22\end{array}$ & $\begin{array}{r}2.01 \\
\pm 0.54\end{array}$ & $\begin{array}{r}1.84 \\
\pm 0.49\end{array}$ \\
\hline
\end{tabular}

a Two diabetics receiving treatment omitted

and at $120 \mathrm{~min}$ were significantly higher than in the controls $(P<0.02$ and $<0.005$ respectively). The "active" acromegalics had significantly higher serum IRI values compared with the controls at 60 minutes $(P<0.025)$ and $90 \mathrm{~min}(P<0.05)$.
Correlation of $\triangle B G$ to $\triangle I R I$. A positive correlation existed between the changes in $B G(\triangle B G)$ and the changes in serum IRI ( $\triangle$ IRI) from the fasting level both in the controls and the "inactive" acromegalies at $30 \mathrm{~min}$ (correlation coefficient $r=0.56, P<0.05$, 
and $r=0.57, P<0.01$ respectively). At $90 \mathrm{~min}$ and at 120 min a correlation between $\Delta \mathrm{BG}$ and $\Delta \mathrm{IRI}$ was found only in the "inactive" acromegalics $(r=0.60$, $P<0.02$, and $r=0.63, P<0.005$ respectively). On the other hand, a positive correlation existed in the controls between the maximal increase in the BG over the fasting level and the increase in serum IRI at the same moment over the fasting level $(r=0.57, P<$ 0.025). This did not hold for the "inactive" acromegalics.

Growth hormone (GH). The mean values $\pm \mathrm{SE}$ in the fasting state and after glucose load are shown in Fig. 3. One of the four female controls had a high fasting GH level of $31 \mathrm{ng} / \mathrm{ml}$, which fell after glucose administration to $5 \mathrm{ng} / \mathrm{ml}$ at 60 minutes and $3.3 \mathrm{ng} / \mathrm{ml}$ at $120 \mathrm{~min}$. The mean fasting $\mathrm{GH}$ value of the nine female "inactive" acromegalics was $8.6 \pm 1.0 \mathrm{ng} / \mathrm{ml}$ and of the seven male "inactive" acromegalics $11.3 \pm 1.6 \mathrm{ng} / \mathrm{ml}$. The "inactive" acromegalics did not show marked changes in serum GH values after the glucose load, in contrast to the significant drop from the fasting level in the controls. GH levels in the "active" acromegalics were significantly higher than in the controls throughout the test, and usually higher than the levels in the "inactives".

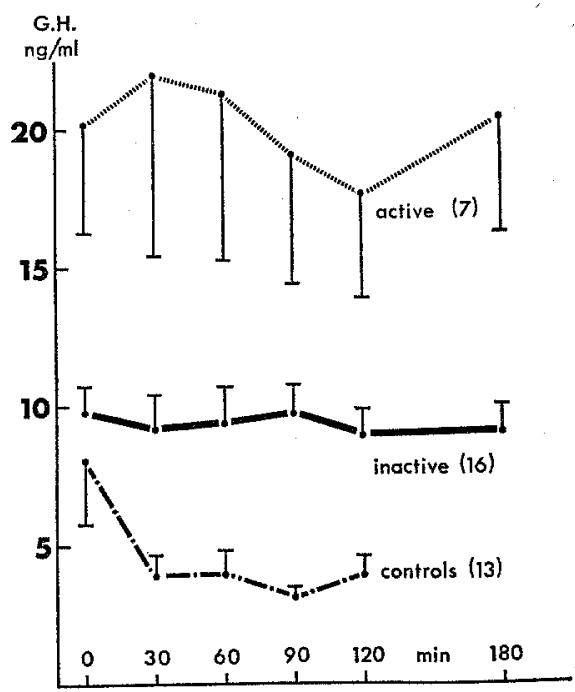

Fig. 3. Serum growth hormone $(\mathrm{ng} / \mathrm{ml})$, mean \pm SE before and after oral glucose load $(100 \mathrm{~g})$ in controls and "inactive" and "active" acromegalics

Correlation of GH to IRI. A significant correlation existed between fasting GH level and fasting serum IRI value in the controls $(r=0.61, P<0.01)$, but not in the two groups of patients with acromegaly. No correlation was found between fasting GH level and the maximal increase in serum IRI over the fasting level in any of the three groups.

\section{Discussion}

KARAMI and co-workers [11] found the serum insulin response to glucose load normal in inactive acromegal- ics, and increased in active acromegalics. The elevated serum insulin levels of the active acromegalics corresponded with the clinical criteria of activity regardless of the presence of diabetes. Some authors report an increased insulin response to glucose load after radiation treatment for acromegaly [1], others a decrease after radioactive yttrium $\left({ }^{90} \mathrm{Y}\right)$ implantation [15], and after treatment by hypophysectomy or X-rays [19].

LUFT and co-workers [13] described a normalization of the insulin response to glucose infusion after treatment of acromegaly with surgical hypophysectomy or ${ }^{90} \mathrm{Y}$ implantation in patients with normal pre-treatment k-values. In a group of three patients with impaired glucose tolerance before treatment, the glucose tolerance became normal postoperatively in two cases. However, the insulin response remained low in this group. The authors suggested that diabetes develops in acromegaly only in pre-diabetic individuals.

BoDEN et al. [3], in their recent report on the GH response to intravenous glucose load in 17 acromegalics, 15 of whom had received conventional X-ray therapy, considered that their findings indicated a peripheral insensitivity to circulating endogenous insulin. The authors did not comment on the degree of activity of their patients' acromegaly, but the mean fasting GH value was $36.8 \pm 5.2 \mathrm{~m} \mu \mathrm{g} / \mathrm{ml}$ and all individual fasting values exceeded the mean fasting values of normal subjects.

Our results indicate hyperinsulinism in both "inactive" and "active" acromegalic patients in the fasting state and after an oral glucose load. The sustained hyperresponsiveness in serum IRI to glucose load in the "inactive" acromegalies was reflected also in the longer-lasting correlation between changes in $\mathrm{BG}$ and changes in serum IRI compared with the controls. On the other hand, the "inactive" acromegalic group showed a lack of correlation between the maximal increase in $\mathrm{BG}$ and the corresponding increase in serum. IRI over the fasting value. Furthermore, the "inactive" acromegalics had higher IRI/BG ratios than the controls. These two observations may indicate an excessive insulin secretion in the "inactive" acromegalics in response to a given glucose stimulation.

The hyperresponsiveness in serum IRI to glucose load in clinically and radiologically "inactive" acromegalics was observed one and a half to 12 years after treatment, suggesting that chronically elevated levels of circulating GH may have led to permanent changes in the responsiveness of the pancreatic islets to glucose stimulation. On the other hand, external irradiation may not arrest acromegaly totally, and therefore GH stimulation of the pancreatic islets might continue after treatment; this would be in keeping with the lack of suppression by oral glucose of $\mathrm{GH}$ levels in the "inactive" group. Our findings differ from those of Karair et al. [11], who did not find insulin hyperresponsiveness in "inactive" acromegalics. The patients in our series were not clinically obese. Two "inactive" acromegalics were $135 \%$ of the average weights for age 
and sex and two "active" acromegalics were $131 \%$ and $136 \%$ of average woights respectively. This increase over the average might be due to acromegaly itself.

The non-suppression or rise in serum GH levels after glucose load in the "active" acromegalics in our series correspond well with data reported earlier [18, $2,4,10,17$, and 5]. The question of the suppression of GH by glucose load in inactive acromegalics remains controversial: GREenwoon et al. [6] did not find it after a meal in "burnt-out" acromegaly, nor did they find differences in postcibal serum GH values in acromegalics of varying clinical activity. SöNKsEN and co-workers [19] described a patient whose posthypophysectomy serum GH dropped after a glucose load. In our series, the fasting GH levels in the controls were about equal to those in the "inactive" acromegalics, but glucose did not suppress serum GH in the latter.

Acknowledgements. We thank Mrs. B. Brown, Mrs. R. voN HAOFF and Miss B. JoNhs for excellent technical assistance. The help of Dr. H. REID in the preparation of the manuscript is acknowledged with thanlss.

\section{References}

1. Beok, P., D. S. Schatch, M. L. Parker, D.M. Kipnis, and W.H. Daugraday: Correlative studies of growth hormone and insulin plasma concentrations with metabolic abnormalities in acromegaly. J. Lab. clin. Med. 66, 366-379 (1965).

2. - M.L. Parker, and W.H. Daughaday: Paradoxical hypersecretion of growth hormone in response to glucose. J. clin. Endocr. 26, 463-469 (1966).

3. BoDEN, G., J.S. SOEIDNER, J. STELNKE, and G.W. THORN: Serum human growth hormone (HGH) response to IV glucose: Diagnosis of acromegaly in females and males. Metabolism 17, 1-9 (1968).

4. Derot, M., G. Rosseuth, R. Assan, P. Freyohet, and G. Tchoвroutsky: Taux plasmatiques de l'hormone de eroissance et de l'insuline chez des acromégales. Ann. Findoer. (Paris) 27, 776-783 (1966).

5. EARLI, J.M., C.L. Sparks, and P.H. Forsham: Glucose suppression of serum growth hormone in the diagnosis of acromegaly. JAMA 201, 628-630 (1967).

6. Greenwood, F.C., H.J. Stewart, A.P.M. Forrest, and R.G. Woov: Plasma-growth-hormone levels in untreated acromegaly and after radioactive implants into the pituitary. Lancet 1965 II, 555-558.

7. GRodskY, G.M., and P.H. ForshaM: An immuno. chemical assay of total extractable insulin in man. J. clin. Invest. 39, 1070-1079 (1960).

8. Herbert, V., K-S. Lau, C.W. GotTuieb, and S.J. BLEICHER : Coated charcoal immunoassay of insulin. J. clin. Endocr. 25, 1375-1384 (1965).

9. Hofmman, W.S.: A rapid photoelectric method for the determination of glucose in blood and urine. J. biol. Chern. 120, 51-55 (1937).

10. IrIe, M., M. Sakuma, K. Shrzume, and K. Nakao: Study on the evaluation of activity in acromegaly. Endocr. jap. 14, 17-22 (1967).

11. Karam, J.H., G.M. Grodsky, F.C. Pavlatos, and P.H. FoRshaM: Critical factors in excessive seruminsulin response to glucose. Obesity in maturity-onset diabetes and growth hormone in acromegaly. Lancet $1965 \mathrm{I}, 286-289$.

12. KNICK, B.: Diagnosis of diabetes. Definitions and classification of diabetes mellitus, p. 39. Mannheim: Boehringer 1967.

13. Luft, R., E. Cerasi, and C.A. Hamberger: Studies on the pathogenesis of diabetes in acromegaly. Acta endocr. (Kobenhavn) 56, 593-607 (1967).

14. Morgar, C.R.: Human growth hormone immunoassay: Two-antibody method using I-125 tracer. Proc. Soc. exp. Biol. 121, 62-64 (1966).

15. Pearson, O.H., C.N. Shealy, B. Kaufman, and N. SaMAax: Anterior pituitary function. Clin. Neurosurg. $13,265-276$ (1966).

16. RANDLE, P.J.: Plasma-insulin activity in acromegaly. Lancot 1954 I, $441-444$.

17. Roth, J., S.M. Glick, P. Cuatrecasas, and C.S. HoLLANDER: Acromegaly and other disorders of growth hormone secretion. Ann. Int. Med. 66, 760788 (1967).

18. - - R.S. YALOW, and S.A. Berson: Secretion of human growth hormone: Physiologic and experimental modification. Metabolism 12, 577-579 (1963).

19. Sönksen, P.H., F.C. GReinwood, J.P. Eluts, C. LOWY, A. RUTHERFord, and J.D.N. NABARRO: Changes of carbohydrate tolerance in acromegaly with progress of the disease and in response to treatment. J. clin. Endocr. 27, 1418-1430 (1967).

20. YALOW, R.S., and S.A. BERSON: Immunoassay of endogenous plasma insulin in man. J. clin. Invest. 39, $1157-1175(1960)$.

Dr. H.K. ÅKERBLOM

Dr. P.R. NEWMAN

Dr. J.W. Mrakin

Dr. J.M. MaRTiN

Dr. W.J.K. SIMIPSON

Research Institute

The Hospital for Sick Children

555 University Avenue

Toronto 2, Ontario 